\title{
PENGARUH GOOD CORPORATE GOVERNANCE TERHADAP KINERJA KEUANGAN PERUSAHAAN PERBANKAN YANG TERDAFTAR DI BURSA EFEK INDONESIA
}

\author{
Christina Verawaty Situmorang ${ }^{a^{*}}$, Arthur Simanjuntak ${ }^{a}$ \\ $a$ Universitas Methodist Indonesia
}

Diterima Juni 2019; Disetujui Agustus 2019; Dipublikasikan November 2019

\begin{abstract}
Abstrak
Penelitian ini bertujuan untuk menguji dan menganalisis pengaruh good corporate governance terhadap kinerja keuangan perusahaan. Good corporate governance dalam penelitian ini diproksikan dengan persentase kepemilikan institusional, komposisi dewan direksi dan komposisi komisaris independen. Kinerja keuangan perusahaan perbankan diukur dengan Return on Equity (ROE). Populasi penelitian ini adalah perusahaan perbankan Buku II dan III yang terdaftar di Bursa Efek Indonesia (BEI) yang berjumlah 29 perusahaan. Teknik pemilihan sampel menggunakan purposive sampling sehingga diperoleh 19 perusahaan. Jenis data yang digunakan yaitu data sekunder. Teknik analisis data dalam penelitian ini menggunakan analisis regresi linear berganda. Hasil penelitian ini secara parsial menunjukkan bahwa persentase kepemilikan institusional, komposisi dewan direksi, dan komposisi komisaris independen tidak berpengaruh signifikan dengan arah koefisien negatif terhadap ROE. sedangkan secara simultan persentase kepemilikan institusional, komposisi dewan direksi dan komposisi komisaris independen berpengaruh signifikan terhadap ROE dengan arah koefisien positif.

Kata Kunci : Tata Kelola Perusahaan, Kinerja Keuangan, Sektor Perbankan
\end{abstract}

\begin{abstract}
This study aims to examine and analyze the influence of good corporate governance on corporate financial performance. Good corporate governance in this study is proxied by percentage of institutional ownership, composition of board of directors and composition of independent commissioner. The financial performance of a banking company is measured by Return on Equity (ROE). The population of this study are banking companies Book II and III listed on the Indonesia Stock Exchange (BEI), amounting to 29 companies. The technique of the sample using purposive sampling obtained 19 companies. The type of data used is secondary data. Data analysis technique in this research use multiple linear regression analysis. The results of this study partially indicate that the percentage of institutional ownership, composition of board of directors and composition of independent commissioner has no significant effect with the direction of negative coefficient on ROE. While the simultaneous percentage of institutional ownership, the composition of the board of directors and the composition of independent commissioners composition have significant effect on ROE with positive coefficient direction.
\end{abstract}

Keyword: Good Corporate Governance, Financial Performance, Banking Sector

How To Cite: Situmorang, C. H. \& Simanjuntak, A. (2019) Pengaruh Good Corporate Governance Terhadap Kinerja Keuangan Perusahaan Perbankan Yang Terdaftar Di Bursa Efek Indonesia. Jurnal Akuntansi dan Bisnis: Jurnal Program Studi Akuntansi, 5 (2): 160-169

* email: ciiiiztina87@gmail.com

\section{PENDAHULUAN}

Kinerja keuangan Perbankan merupakan salah satu faktor untuk meningkatkan nilai perusahaan guna meningkatkan kesejahteraan para pemiliknya (Aluy, et al. 2017). 
Kinerja perusahaan Perbankan dapat diukur dari berbagai rasio seperti rasio solvabilitas, rasio likuiditas, dan rasio profitabilitas (Octaviani, S., \& Komalasari, D. 2017). Dalam penelitian ini, kinerja keuangan diukur menggunakan rasio profitabilitas. Gambaran profitabilitas suatu bank dapat diukur dengan Return On Equity (ROE). ROE merupakan perbandingan antara laba bersih sesudah pajak dengan modal sendiri (Deitiana, T. 2013). Semakin tinggi nilai ROE berarti perusahaan semakin efektif dalam memanfaatkan modal yang ada untuk menghasilkan laba yang maksimal, sehingga investor tertarik untuk menanamkan modalnya dalam perusahaan dikarenakan tingkat return modal yang tinggi, sebaliknya apabila ROE mengalami penurunan maka ketertarikan investor juga akan berkurang (Riana, I. K. T., \& Dewi, S. K. S. 2015).

Good corporate governance merupakan salah satu elemen dalam meningkatkan efisiensi ekonomi yang meliputi serangkaian hubungan antara pihak internal maupun pihak eksternal perusahaan (Lestari, E. D., \& Muid, D. (2011). Konsep Corporate Governance diajukan demi tercapainya transparansi pengelolaan perusahaan bagi semua pengguna laporan keuangan, bila konsep ini dijalankan dengan baik maka kepercayaan baik investor maupun pihak lainnya akan meningkat yang akan berdampak terhadap meningkatnya kinerja perusahaan sehingga dapat menguntungkan berbagai pihak. Good Corporate Governance juga dapat dijadikan sebagai alat untuk menghadapi persaingan era globalisasi sehingga perusahaan khususnya Perbankan Indonesia tidak tertindas dalam era globalisasi dan persaingan bebas (Dewayanto, T. 2010).

Masalah Good Corporate Governance kembali meningkat dengan pesat seiring terbukanya skandal kasus PT Lippo Bank Tbk yang memanipulasi laporan keuangan, ini membuktikan bahwa masih lemahnya penerapan Good Corporate Governance walaupun telah menjauhi periode krisis moneter (Sukamulja, S. 2005). Dunia perbankan Good Corporate Governance belum ditetapkan secara utuh terlihat dari banyaknya perusahaan perbankan yang mengalami masalah dikarenakan tata kelola perusahaan yang buruk seperti kasus Bank Century yang mengalami likuiditas yang serius. Bercermin dari berbagai kasus yang ada khususnya di Indonesia maka Good Corporate Governance sangatlah penting dan merupakan kebutuhan yang harus dipenuhi dan dijalankan agar kelangsungan hidup suatu perusahaan dapat berjalan dengan baik. Dengan menerapkan prinsip tata kelola perusahaan (GCG) dalam mekanisme perusahaan akan meningkatkan nilai perusahaan yang akan berpengaruh terhadap kelangsungan hidup dan kinerja perusahaan (Muryati \& Suardikha. 2014). Penelitian ini memproksikan Good Corporate Governance dengan kepemilikan institusional, dewan direksi dan komisi independen. Persentase Kepemilikan institusional merupakan persentase kepemilikan saham perusahaan oleh institusi atau lembaga, semakin besar kepemilikan institusional dan suatu perusahaan akan semakin besar pula pengaruhnya, dikarenakan beberapa pengambilan keputusan diperlukan persetujuan oleh pihak-pihak yang memiliki saham dalam perusahaan tersebut seperti: pengangkatan direksi, memutuskan permodalan perusahaan baik penambahan maupun pengurangan modal, keputusan inilah yang akan berdampak terhadap kinerja keuangan perusahaan.

Komposisi Dewan direksi adalah Organ Perseroan yang berwenang dan bertanggung jawab penuh atas pengurusan Perseroan untuk kepentingan Perseroan, sesuai dengan maksud dan tujuan Perseroan serta mewakili Perseroan, baik di dalam maupun di luar pengadilan sesuai dengan ketentuan anggaran dasar (Tjandra, E. 2015). Dewan direksi yang diangkat menjadi pemimpin dalam perusahaan memiliki peran yang aktif dikarenakan dapat memastikan apakah pihak manajemen atau pihak yang berada dibawahnya melakukan tugasnya sesuai dengan tujuan dan perencanaan perusahaan. 
Komposisi Komisaris independen memiliki peran untuk menciptakan iklim yang lebih objektif dan menempatkan kesetaraan di antara berbagai kepentingan termasuk kepentingan perusahaan dan kepentingan stakeholder sebagai prinsip utama dalam pengambilan keputusan oleh dewan komisaris, dan mendorong diterapkannya prinsip tata kelola di dalam perusahaan (Rifai, B. 2009).

Penelitian ini memiliki tujuan untuk menguji dan menganalisis pengaruh Persentase Kepemilikan institusional, Komposisi Dewan direksi, Komposisi Komisaris independen terhadap kinerja perusahaan Perbankan yang terdaftar di Bursa Efek Indonesia baik secara parsial maupun secara simultan. Kemudian, dari beberapa penelitian yang telah dilakukan sebelumnya terdapat perbedaan hasil penelitian, menurut penelitian yang dilakukan oleh (Prantama et al. 2015), kepemilikan institusional tidak berpengaruh signifikan terhadap kinerja keuangan (ROE). Sedangkan menurut (Rizky Arifani 2016), (Putra \& Nuzula 2017), kepemilikan institusional memiliki pengaruh yang signifikan terhadap (ROE). Penelitian yang dilakukan (Prantama et al. 2015) serta (Rizky Arifani 2016), menunjukan bahwa Komisaris independen memiliki pengaruh signifikan terhadap kinerja keuangan (ROE). Sedangkan penelitian yang dilakukan (Putra \& Nuzula 2017) menunjukkan hasil yang berbeda yaitu Dewan komisaris independen tidak memiliki pengaruh yang signifikan terhadap ROE. Demikian juga penelitian yang dilakukan (Wicaksono 2014) dan (Putra \& Nuzula 2017) yang menunjukan komite audit tidak berpengaruh signifikan terhadap ROE.

\section{Kinerja Perbankan}

Menurut (Jumingan 2014) Kinerja bank secara keseluruhan merupakan gambaran prestasi yang dicapai bank dan operasionalnya, baik menyangkut aspek keuangan, pemasaran, peghimpunan dan penyaluran dana, teknologi maupun sumber daya manusia. Tujuannya, yaitu untuk mendorong kinerja seseorang agar bisa berada diatas rata-rata. Dalam menilai kinerja keuangan, tolak ukur yang digunakan dalam penelitian ini adalah rasio profitabilitas. Kemudian, menurut (Sofyan 2013) Rasio profitabilitas merupakan rasio yang menggambarkan kemampuan perusahaan dalam mendapatkan laba melalui semua kemampuan, dan sumber yang ada seperti kegiatan penjualan, kas, modal, jumlah karyawan, jumlah cabang dan sebagainya. Gambaran profitabilitas suatu bank dapat diukur dengan Return On Equity (ROE). Serta lebih lanjut menurut (Hery 2017) ROE merupakan merupakan rasio yang menunjukkan seberapa besar kontribusi ekuitas dalam menciptakan laba bersih.

\section{Definisi Good Corporate Governance}

Menurut (Sedarmayanti 2012) corporate governance adalah sistem, proses, dan seperangkat peraturan yang mengatur hubungan antara berbagai pihak yang berkepentingan terutama dalam arti sempit, hubungan antara pemegang saham, dewan komisaris, dan dewan direksi demi tercapainya tujuan organisasi. Corporate governance dimaksudkan untuk mengatur hubungan ini dengan mencegah terjadinya kesalahan signifikansi dalam strategi korporasi dan untuk memastikan kesalahan yang terjadi dapat segera diperbaiki. Peraturan Menteri Keuangan Republik Indonesia Nomor 88 /PMK.06/2015 mendefiniskan Tata Kelola Perusahaan Yang Baik (Good Corporate Governance) sebagai suatu sistem yang dirancang untuk mengarahkan pengelolaan perusahaan perseroan berdasarkan prinsip-prinsip transparansi, kemandirian, akuntabilitas, pertanggungjawaban, dan kewajaran, untuk pencapaian penyelenggaraan kegiatan usaha yang memperhatikan kepentingan setiap pihak yang terkait dalam 
penyelenggaraan kegiatan usaha, berlandaskan peraturan perundang-undangan dan praktik-praktik yang berlaku umum.

\section{Pengaruh Good Corporate Governance terhadap Kinerja Keuangan}

Penerapan GCG (Good Corporate Governance) menunjukan betapa pentingnya dalam mendukung tercapainya tujuan perusahaan dan dasar dari pengambilan kebijakan-kebijakan perusahaan sehingga memberikan keuntungan kepada berbagai pihak yang berkepentingan (stakeholder dan shareholder). Penerapan GCG juga mampu membantu perusahaan untuk mengelola dengan baik kinerja keuangan suatu perusahaan agar mencapai tujuan keberhasilan dari segala aktivitas-aktivitas yang sudah dilalui selama satu periode (Ainurrofiq 2016). Hasil penelitian (Nurcahyani, Suhadak dan Hidayat 2013) menemukan adanya hubungan positif antara corporate governance dengan kinerja perusahaan yang diukur dengan ROE. Dengan adanya mekanisme good corporate governance yang baik diharapkan mampu meningkatkan kinerja perbankan. Mekanisme good corporate governance meliputi indikator persentase Kepemilikan Institusional, Komposisi Dewan Direksi, Komposisi Komisaris Independen dan Komposisi Komite Audit

\section{Pengaruh Persentase Kepemilikan Institusional terhadap Kinerja Keuangan}

Kepemilikan institusonal bertindak sebagai pihak yang memonitor secara profesional perkembangan investasi yang ditanamkan oleh pemegang saham. Hal ini memperkecil kemungkinan manajemen untuk melakukan kecurangan sehingga dapat menyelaraskan kepentingan manajemen dan kepentingan stakeholder lainnya untuk meningkatkan kinerja perusahaan. Kepemilikan Institusional dalam proporsi yang besar akan mempengaruhi kinerja keuangan perusahaan (Dini Kristi 2014).

\section{Pengaruh Komposisi Dewan Direksi terhadap Kinerja Keuangan}

Komposisi dewan direksi dapat mempengaruhi efektif tidaknya aktivitas monitoring. Selain itu juga dapat mempengaruhi hubungan kepemilikan institusional dan kepemilikan manajerial terhadap kinerja perusahaan. Semakin besar Komposisi dewan direksi akan berdampak positif terhadap kinerja perusahaan dan nilai perusahaan (Alifia Faizun Nahari 2016).

\section{Pengaruh Komposisi Komisaris Independen terhadap Kinerja Keuangan}

Komisaris independen merupakan posisi terbaik untuk melaksanakan fungsi monitoring agar tercipta perusahaan yang good corporate governance. Semakin besar jumlah komisaris independen maka keputusan yang dibuat dewan komisaris lebih mengutamakan kepada kepentingan perusahaan, sehingga berpengaruh terhadap kinerja perusahaan (Rizky Arifani 2016). Hasil penelitian sebelumnya menemukan bahwa keberadaan komisaris idependen berpengaruh signifikan terhadap nilai perusahaan (Prantama et al. 2015).

Pengaruh persentase kepemilikan institusional, komposisi dewan direksi dan komisaris independen terhadap kinerja keuangan.

Return on equity capital merupakan rasio yang digunakan untuk mengukur kemampuan manajemn bank dalam mengelola capital yang ada untuk mendapatkan net income (Kasmir 2012). Menurut (Hery 2015) Semakin tinggi hasil pengembalian atas ekuitas berarti semakin tinggi pula jumlah laba bersih yang dihasilkan dari setiap rupiah dana yang tertanam dalam ekuitas. Sebaliknya, Semakin rendah hasil pengembalian atas 
ekuitas berarti semakin rendah pula jumlah laba bersih yang dihasilkan. Salah satu faktor yang mempengaruhi tinggi rendahnya ROE (Retrun on Equity) adalah tata kelola perusahaan (Good Corporate Governance) yang diproksikan dengan persentase kepemilikan institusional, komposisi dewan direksi dan komposisi komisaris independen.

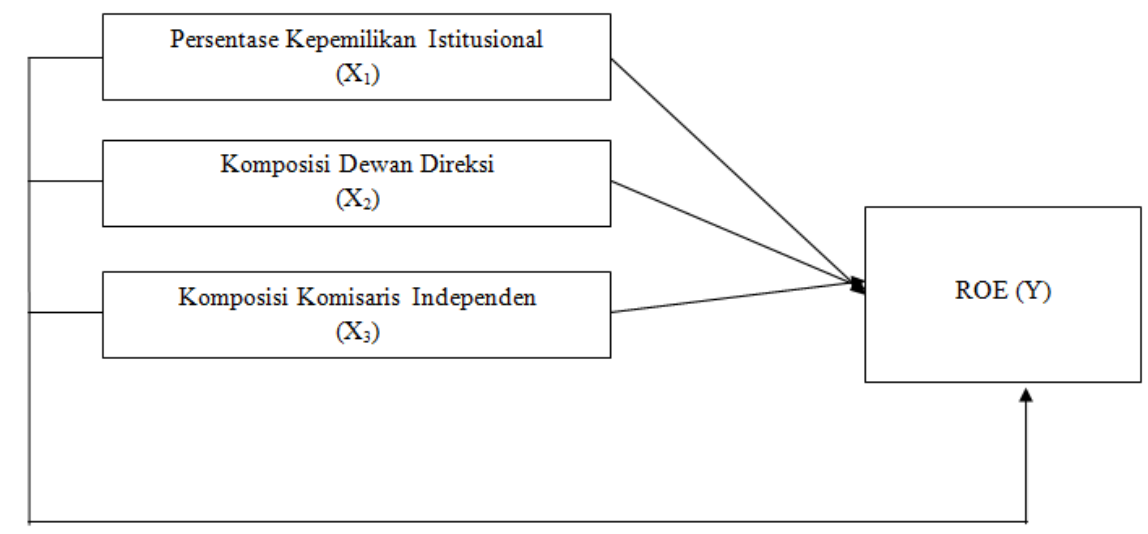

Gambar 1. Kerangka Konseptual

\section{METODE PENELITIAN}

\section{Jenis dan Sumber Data}

Jenis data yang digunakan peneliti dalam penelitian ini adalah data sekunder. Data sekunder yang digunakan dalam penelitian ini adalah laporan keuangan perusahaan Perbankan yang terdaftar di Bursa Efek Indonesia.

\section{Populasi dan Sampel}

Populasi menurut (Sugiyono 2012) adalah wilayah generalisasi yang terdiri atas; objek atau subjek yang mempunyai kualitas dan karakteristik tertentu yang ditetapkan oleh peneliti untuk dipelajari dan kemudian ditarik kesimpulannya Populasi penelitian ini adalah seluruh perusahaan perbankan Buku II dan III yang terdaftar di Bursa Efek Indonesia, yaitu sebanyak 29 perusahaan. Menurut (Juliansyah Noor 2013) Sampel adalah sejumlah anggota yang dipilih dari populasi. Teknik pengambilan sampel dalam penelitian ini menggunakan teknik purposive sampling, yaitu suatu pertimbangan tertentu yang dibuat oleh peneliti sendiri, berdasarkan ciri atau sifat-sifat populasi yang sudah diketahui sebelumnya

\section{Variabel independen}

Adapun variabel independen dalam penelitian ini adalah Persentase Kepemilikan institusional, Komposisi Dewan direksi, Komposisi dan Komisaris independen.

\section{Variabel dependen}

Variabel dependen yang digunakan oleh peneliti adalah ROE (Return On Equity) yang merupakan rasio untuk mengukur efektivitas perusahaan dalam menghasilkan laba dengan memanfaat modal yang dimiliki.

\section{Teknik Analisa Data}

Teknik analisis dalam penelitian ini menggunakan regresi linier berganda (multiple liniear regression). Analisis regresi berganda dapat menjelaskan pengaruh 
antara variabel terikat dengan variabel bebas. Untuk mempermudah analisis dalam penelitian ini digunakan alat bantu berupa software SPSS (Statistical Package for Social Sience) 23.

\section{Uji Asumsi Klasik dan Uji Normalitas}

Uji asumsi klasik digunakan untuk mengetahui ada tidaknya normalitas residual, multikolinieritas, autokolerasi, dan heterokedastis pada model regresi. Model regresi dapat disebut sebagai model yang baik jika model tersebut memenuhi beberapa asumsi klasik, yaitu data residual terdistribusi normal, tidak ada multikoliniearitas, autokolerasi dan heteroskedastisitas. Uji normalitas dilakukan untuk mengetahui apakah data yang diambil berasal dari populasi yang berdistribusi normal atau tidak. Dalam penelitian ini digunakan analisis statistik dengan uji Kolmogorov Smirnov. Pengambilan keputusan mengenai normalitas adalah jika nilai Sig. atau signifikan $<0.05$, maka distribusi data tidak normal. Atau jika nilai Sig. atau Signifikan $>0.05$, maka distribusi data normal.

\section{Uji Multikolinieritas}

Uji multikolinieritas bertujuan untuk meneliti apakah dalam model regresi ditemukan adanya korelasi di antara variabel independen. Batasan umum yang dipakai untuk menunjukkan adanaya multikolinieritas adalah nilai tolerance $>0.1$ atau VIF $<10$.

\section{Uji Autokolerasi}

Uji Autokorelasi bertujuan menguji apakah dalam model regresi linear ada korelasi antara kesalahan pengganggu pada periode $t$ dengan kesalahan pengganggu pada periode t-1 (sebelumnya). Untuk mendeteksi adanya autokorelasi bisa digunakan tes Durbin Watson (DW)

\section{Analisis Regresi}

Analisis data dalam penelitian ini menggunakan analisis regresi linier berganda.. Model regresi yang digunakan adalah sebagai berikut

Keterangan;

$$
\mathrm{Y}=\mathrm{a}+\mathrm{b}_{1} \mathrm{X}_{1}+\mathrm{b}_{2} \mathrm{X}_{2}+\mathrm{b}_{3} \mathrm{X}_{3}+\mathrm{e}
$$

$\mathrm{Y}=$ Kinerja Keuangan (ROE)

$\mathrm{a}=$ Konstanta

$\mathrm{b}=$ Koefisien Regresi

$\mathrm{X}_{1}=$ Persentase Kepemilikan Institusional

$\mathrm{X}_{2}=$ Komposisi Dewan Direksi

$\mathrm{X}_{3}=$ Komposisi Komisaris Independen

$\mathrm{e}=$ error

\section{Uji Hipotesis}

Secara umum hipotesis merupakan suatu pernyataan yang masih lemah dan memerlukan suatu pembuktian untuk menegaskan apakah hipotesis tersebut dapat diterima atau ditolak berdasarkan fakta atau data empiris yang telah dikumpulkan dalam penelitian. Uji hipotesis dalam penelitian ini menggunakan analisis regresi dengan uji parsial (uji t), uji simultan (uji F), dan Koefisien determinasi ( $\mathrm{R}^{2}$ ). 
Situmorang, C. H. \& Simanjuntak, A. (2019) Pengaruh Good Corporate Governance Terhadap Kinerja Keuangan Perusahaan Perbankan...

\section{HASIL DAN PEMBAHASAN}

Pada Tabel 1 dapat dilihat nilai kolomogorov-Smirnov (K-S) sebesar 0,068 dengan probabilitas signifikan 0,200 dan nilainya besar dari $(>) 0,05$, sehingga dapat disimpulkan bahwa data berdistribusi normal.

Tabel 1 Uji Normalitas

\begin{tabular}{cc}
\hline & Unstandardized Residual \\
\hline $\mathrm{N}$ & 95 \\
Mean & .0000000 \\
Std. Deviation & .06692679 \\
Absolute & .068 \\
Positive & .068 \\
Negative & -.047 \\
Test Statistic & .068 \\
Asymp. Sig. 2-tailed & .200 \\
\hline
\end{tabular}

Tabel 2 Uji Autokolerasi

\begin{tabular}{ccccc}
\hline $\mathrm{R}$ & R Square & $\begin{array}{c}\text { Adjusted R } \\
\text { Square }\end{array}$ & $\begin{array}{c}\text { Std. Error of the } \\
\text { Estimate }\end{array}$ & Durbin-Watson \\
\hline .195 & .038 & .006 & .06802 & 1.125 \\
\hline
\end{tabular}

Berdasarkan Tabel 2 diatas menunjukkan bahwa nilai Durbin Watson 1,125. Dilihat dari tabel Durbin Watson (DW) pada signifikan 5\% dengan jumlah sampel 95 dan jumlah variabel independen $4(\mathrm{~K}=3)$ maka dapat didapat $\mathrm{dl}=1,6015$, dan $\mathrm{du}=1,7316$. Dinyatakan tidak ada autokolerasi apabila $0<$ DW $<$ dl atau $0<1,125<1,6015$ atau dapat disimpulkan bahwa tidak terjadi masalah autokorelasi. Berdasarkan Tabel 3 tersebut juga memperlihatkan bahwa nilai $r$ adalah 0,195 berarti hubungan antara variabel persentase kepemilikan institusional, komposisi dewan direksi dan komposisi komisaris independen terhadap kinerja keuangan adalah sebesar 19,50\% artinya hubungan korelasi tersebut lemah karena nilai $\mathrm{r}$ berada dibawah 0,5 atau $50 \%$. Selain itu nilai $R$ Square sebesar 0,038 yang berarti 3,8\% faktor-faktor dari kinerja keuangan dapat dijelaskan oleh variabel persentase kepemilikan institusional, komposisi dewan direksi, dan komposisi komisaris independen, sedangkan selebihnya sebesar 96,2\% dijelaskan oleh faktor lain yang tidak diteliti di dalam penelitian ini.

\section{Analisis Regresi dan Uji Hipotesis}

Untuk menguji hipotesis, peneliti menggunakan analisis regresi berganda. Hasil regresi penelitian dapat dilihat dalam Tabel 3. Berdasarkan Tabel 3. model persamaan regresi linier berganda dalam penelitian ini adalah sebagai berikut:

$$
\begin{aligned}
& \mathrm{Y}=\mathrm{a}+\mathrm{b} 1 \mathrm{X} 1+\mathrm{b} 2 \mathrm{X} 2+\mathrm{b} 3 \mathrm{X} 3+\mathrm{e}, \text { maka } \\
& \mathrm{Y}=0,61-0,034 \mathrm{X} 1+0,003 \mathrm{X} 2+0,071 \mathrm{X} 3+\mathrm{e}
\end{aligned}
$$

Tabel 3 berikut menginterpretasikan untuk tiap variabel penelitian adalah; Variabel Persentase kepemilikan institusional (X1) tidak berpengaruh signifikan terhadap variabel kinerja keuangan (Y) yang diproksikan dengan ROE karena nilai signifikan 0,09 $>0,05$ dan nilai thitung $-1,066<$ tabel 1,9852 dengan arah koefisien negatif. Variabel Komposisi dewan direksi (X2) tidak berpengaruh signifikan terhadap variabel kinerja keuangan (Y) yang diproksikan dengan ROE karena nilai signifikan 0,289 > 0,05 dan nilai thitung 1,669 < tabel 1,9852 dengan arah koefisien negatif. Variabel Komposisi komisaris independen (X3) tidak berpengaruh signifikan terhadap variabel kinerja keuangan (Y) yang diproksikan dengan ROE karena nilai signifikan 0,628>0,05 dan nilai thitung 0,487 < ttabel 1,982 dengan arah koefisien negatif. Berdasarkan Tabel 3 juga dapat dilihat bahwa 
keseluruhan variabel memiliki nilai toleran $>0,1$ dan nilai VIF $<10$. Dengan demikian dapat disimpulkan bahwa variabel independen dari penelitian ini terbebas dari multikolinearitas.

Tabel 3 Regresi Linier Berganda dan Uji Hipotesis

\begin{tabular}{cccccccc}
\hline & \multicolumn{2}{c}{$\begin{array}{c}\text { Unstandardized } \\
\text { Coefficients }\end{array}$} & $\begin{array}{c}\text { Standardized } \\
\text { Coefficients }\end{array}$ & \multicolumn{3}{c}{ Collinearity Statistics } \\
Model & $\mathrm{B}$ & Std. Error & Beta & $\mathrm{t}$ & Sig. & Tolerance & VIF \\
\hline Constant & .102 & .061 & & 1.674 & .098 & & \\
Kepemilikan Institusional & -.036 & .034 & -.113 & -1.066 & .289 & .948 & 1.054 \\
Dewan Direksi & .006 & .003 & .184 & 1.669 & .099 & .869 & 1.150 \\
Komisaris Independen & .034 & .071 & .054 & .487 & .628 & .856 & 1.168 \\
\hline
\end{tabular}

\section{Uji F (Uji Simultan)}

Uji simultan digunakan untuk menunjukkan apakah semua variabel independen yang dimasukkan dalam model regresi berganda memiliki pengaruh secara bersamasama terhadap variabel dependen. Berdasarkan Tabel 4 berikut diperoleh nilai signifikan 0,031 karena signifikansi jauh lebih kecil dari 0,05 dan nilai Fhitung 3,204 > Ftabel 2,70 sehingga variabel persentase kepemilikan institusional, komposisi dewan direksi dan komposisi komisaris independen memiliki pengaruh yang signifikan terhadap variabel kinerja keuangan secara simultan atau bersama-sama.

Tabel 4. Uji simultan (uji-F)

\begin{tabular}{cccccc}
\hline Model & Sum of Squares & df & Mean Square & F & Sig. \\
\hline Regression & .017 & 3 & .006 & 3.204 & .031 \\
Residual & .421 & 91 & .005 & & \\
Total & .438 & 94 & & & \\
\hline
\end{tabular}

Berdasarkan hasil penelitian diatas, maka penulis dapat menguraikan beberapa impikasi penelitian tentang kepemilikan institusional, dewan direksi dan komisaris independen terhadap kinerja keuangan perbankan yang terdaftar di Bursa Efek Indonesia yakni uji asumsi klasik yang menunjukkan bahwa data telah terdistribusi normal dan tidak terdapat multikolinieritas, heteroskedasitas, dan autokorelasi sehingga dapat dilakukan analisis regresi berganda untuk melakukan pengujian hipotesis. Hasil uji koefisien determinasi memperlihatkan bahwa nilai $r$ adalah 0,195 berarti hubungan antara variabel persentase kepemilikan institusional, komposisi dewan direksi dan komposisi komisaris independen terhadap kinerja keuangan adalah sebesar 19,50\% artinya hubungan korelasi tersebut lemah karena nilai $r$ berada dibawah 0,5 atau 50\%. Selain itu nilai $R$ Square sebesar 0,038 yang berarti 3,8\% faktor-faktor dari kinerja keuangan dapat dijelaskan oleh variabel persentase kepemilikan institusional, komposisi dewan direksi dan komposisi komisaris independen, sedangkan selebihnya sebesar 92,2\% dijelaskan oleh faktor lain yang tidak diteliti di dalam penelitian ini. Hasil uji $\mathrm{F}$ diperoleh nilai signifikan 0,031 karena signifikansi jauh lebih kecil dari 0,05 dan nilai Fhitung 3,204 > Ftabel 2,70 sehingga variabel persentase kepemilikan institusional, komposisi dewan direksi dan komposisi komisaris independen memiliki pengaruh yang signifikan terhadap variabel kinerja keuangan secara simultan atau bersama-sama.

Persentase kepemilikan institusional tidak berpengaruh signifikan terhadap kinerja keuangan hal ini sesuai dengan nilai signifikansi t yang lebih besar dari 0,05 yaitu sebesar 0,09 $(0,09>0,05)$ dengan koefisien regresi negatif. Hasil penelitian yang mendukung adalah penelitian yang dilakukan oleh Fadillah (2017) menyatakan bahwa kepemilikan institusional tidak berpengaruh secara signifikan terhadap kinerja 
keuangan (ROE), Hasil penelitian ini bertolak belakang dengan hasil penelitian Aluy (2017) yang menyatakan bahwa kepemilikan institusional berpengaruh terhadap kinerja keuangan (ROE). Berdasarkan hasil penelitian yang diperoleh menunjukkan bahwa komposisi dewan direksi tidak berpengaruh signifikan terhadap kinerja keuangan hal ini sesuai dengan nilai signifikansi t yang lebih besar dari 0,05 yaitu sebesar 0,289 $(0,289>$ $0,05)$ dengan koefisien regresi negatif. Hasil penelitian ini sesuai dengan penelitian yang dilakukan Jati (2009) yang menyatakan jumlah dewan direksi tidak berpengaruh terhadap kinerja perusahaan ,Hasil penelitian ini bertolak belakang dengan penelitian yang dilakukan Ratna (2009) yang menyatakan jumlah dewan direksi berpengaruh terhadap kinerja perusahaan.

Komposisi komisaris independen tidak berpengaruh signifikan terhadap kinerja keuangan hal ini sesuai dengan nilai signifikansi t yang lebih besar dari 0,05 yaitu sebesar 0,628 $(0,628>0.05)$ dengan koefisien regresi positif. Hasil penelitian ini sejalan dengan penelitian yang dilakukan oleh Zabri (2015) yang juga tidak menemukan pengaruh yang signifikan antara proporsi dewan komisaris independen terhadap ROE. Hasil penelitian ini bertolak belakang dengan hasil penelitian Rizky (2016) , Putra (2017) yang menyatakan bahwa dewan komisaris independen berpengaruh terhadap Return on Equity (ROE).

\section{SIMPULAN}

Variabel persentase kepemilikan intitusional seacara parsial tidak berpengaruh terhadap kinerja keuangan. Hal ini menujukan semakin besar persentase kepemilikan institusional tidak menjamin terwujudnya pengendalian terhadap perusahaan untuk meningkatkan kinerja perusahaan.Variabel komposisi dewan direksi secara parsial tidak berpengaruh signifikan terhadap kinerja keuangan. Hal ini menujukan bahwa semakin besar komposisi dewan direksi belum tentu menguntungkan perusahaan, dikarenakan sulitnya koordinasi dan pertukaran pikiran serta saran dari para direksi dalam menjalankan roda kegiatan perusahaan sehingga memperlambat pengambilan keputusan yang berdampak terhadap kinerja perusahaan. Variabel komposisi komisaris independen secara parsial tidak berpengaruh signifikan terhadap kinerja keuangan. Hal ini menujukan bahwa pemilik saham mayoritas mememiliki kendali yang kuat dalam perusahaan sehingga fungsi pengawasan yang dilakukan oleh komisaris independen menjadi tidak efektif. Variabel persentase kepemilikan institusional, komposisi dewan direksi dan komposisi komisaris independen secara simultan berpengaruh signifikan terhadap kinerja keuangan. Dari hasil penelitian ini kedepannya dapat menambah beberapa saran antara lain; penelitian selanjutnya dapat menambah variabel penelitian seperti kepemilikan manajerial dan kepemilikan asing. Menggunakan sampel perusahaan yang tidak hanya pada perusahaan Perbankan Buku II dan III saja, tetapi dapat dikembangkan dengan menggunakan sampel Buku I hingga Buku IV. Penelitian selanjutnya diharapkan menggunakan periode pengamatan yang lebih lama sehingga akan memberikan kemungkinan yang lebih besar untuk memperoleh kondisi yang sebenarnya.

\section{DAFTAR PUSTAKA}

Ainurrofiq, M., (2016). Pengaruh Struktur Modal Dan Good Corporate Governance Terhadap Kinerja Keuangan Pada Perusahaan Barang Dan Konsumsi Yang Terdaftar Di Bei. (Doctoral Dissertation, Perbanas Surabaya).

Alifia Faizun Nahari, (2016). Pengaruh Mekanisme Good Corporate Governance terhadap Kinerja Perbankan Nasional. Universitas Sebelas Maret Institusional Repository, pp.1-8.

Aluy, C. A., Tulung, J. E., \& Tasik, H. H. (2017). Pengaruh Keberadaan Wanita Dalam Manajemen Puncak Dan Kepemilikan Manajerial Terhadap Kinerja Keuangan Perbankan (Studi Pada Bank Bumn Dan Bank 
Swasta Nasional Devisa Di Indonesia). Jurnal EMBA: Jurnal Riset Ekonomi, Manajemen, Bisnis dan Akuntansi, 5(2).

Deitiana, T. (2013). Pengaruh Current Ratio, Return on Equity dan Total Asset Turn Over Terhadap Devidend Payout Ratio dan Implikasi pada Harga Saham Perusahaan LQ 45. Jurnal Bisnis dan Akuntansi, 15(1), 82-88.

Dewayanto, T. (2010). Pengaruh mekanisme Good Corporate Governance Terhadap Kinerja Perbankan Nasional. Fokus Ekonomi: Jurnal Ilmiah Ekonomi, 5(2).

Dini Kristi, 2014. Pengaruh Struktur Good Corporate Governance dan Ukuran Perusahaan terhadap Kinerja Keuangan Perusahaan Manufaktur yang Terdaftar di BEI. Repositori Institusi Universitas Sumatera Utara.

Fadillah, A. R. (2017). Analisis Pengaruh Dewan Komisaris Independen, Kepemilikan Manajerial dan Kepemilikan Institusional terhadap Kinerja Perusahaan yang Terdaftar di LQ45. Jurnal Akuntansi, 12(1), 37-52.

Hery, 2017. Analisis Laporan Keuangan, Jakarta: PT Grasindo.

Hery, 2015. Analisis Laporan Keuangan, Yogyakarta: CAPS.

Jati, F. (2009). Pengaruh struktur corporate governance terhadap kinerja perusahaan manufaktur yang terdaftar di Bursa Efek Indonesia. (Doctoral Dissertation, Gunadarma University)

Juliansyah Noor, (2013). Metodologi Penelitian : Skripsi, Tesis, Disertasi dan Karya Ilmiah, Jakarta: Kencana. Jumingan, (2014). Analisis Laporan Keuangan, Jakarta: PT Bumi Aksara.

Kasmir, (2012). Analisis Laporan Keuangan, Jakarta: PT Raja Grafindo Persada.

Lestari, E. D., \& Muid, D. (2011). Pengaruh Good Corporate Governance Terhadap Kinerja Keuangan (Studi Kasus pada Perusahaan Perbankan yang Terdaftar di Bursa Efek Indonesia Tahun 20072009) (Doctoral dissertation, Universitas Diponegoro).

Muryati, N. N. T. S., \& Suardikha, I. M. S. (2014). Pengaruh Corporate Governance Pada Nilai Perusahaan. Ejurnal Akuntansi, 425-429.

Nurcahyani, Suhadak, Hidayat, R.R., 2013. Pengaruh Penerapan Good Corporate Governance dan Kepemilikan Institusional Terhadap Nilai Perusahaan (Studi Pada Perusahaan Peserta CGPI yang Terdaftar di BEI Tahun 2009-2011)".

Octaviani, S., \& Komalasari, D. (2017). Pengaruh Likuiditas, Profitabilitas, dan Solvabilitas Terhadap Harga Saham. JAK (Jurnal Akuntansi): Kajian Ilmiah Akuntansi, 4(1).

Prantama, A.N., Administrasi, F.I. \& Brawijaya, U., 2015. ( Studi Pada Perusahaan Real Estate \& Property yang Terdaftar Di Bursa Efek Indonesia. Administrasi Bisnis, 1(2), pp.1-6.

Putra, A.S. \& Nuzula, N.F., (2017). Pengaruh Corporate Governance Terhadap Profitabilitas ( Studi Pada Perusahaan Perbankan yang Terdaftar di Bursa Efek Indonesia Periode. Administrasi Bisnis, 47(1), pp.103-112.

Ratna, D. H. (2019). Pengaruh Komisaris Independen, Dewan Direksi, dan Komite Audit Terhadap Kinerja Keuangan (Doctoral dissertation, STIE Perbanas Surabaya).

Riana, I. K. T., \& Dewi, S. K. S. (2015). Peran EPS Dalam Memediasi Pengaruh ROE Terhadap Harga Saham Perusahaan Perbankan Di BEI. E-Jurnal Manajemen, 4(12).

Rifai, B. (2009). Peran Komisaris Independen dalam Mewujudkan Good Corporate Governance di Perusahaan Publik. Ius Quia Iustum Law Journal, 16(3), 396-412.

Rizky Arifani, (2016). Pengaruh Good Corporate Governance Terhadap Kinerja Keuangan Perusahaan (Studi pada Perusahaan yang Tercatat di Bursa Efek Indonesia). Ilmiah Mahasiswa FEB Universitas Brawijaya, 1(2). Available at: https://jimfeb.ub.ac.id/index.php/jimfeb/article/view/431.

Sedarmayanti, 2012. Good Governance \& Good Corporate Governance, Bandung: Mandar Maju.

Sofyan, H., 2013. Analitis Kritis Atas Laporan Keuangan, Jakarta: PT Rajagrafindo Persada.

Sukamulja, S. (2005). Good corporate governance di sektor keuangan: Dampak GCG terhadap kinerja perusahaan (Kasus di Bursa Efek Jakarta). Benefit: Jurnal Manajemen dan Bisnis, 8(1), 1-25.

Sugiyono, 2012. Metode Penelitian Pendidikan, Bandung: Alfabeta.

Tjandra, E. (2015). Pengaruh Good Corporate Governance Terhadap Leverage Dan Profitabilitas Pada Perusahaan Property Dan Real Estate Di Indonesia. Jurnal GEMA AKTUALITA, Vol. 4 No. 2, 2015

Wicaksono, T., 2014. Pengaruh Good Corporate Governance Terhadap Profitabilitas Perusahaan ( Studi Empiris pada Perusahaan Peserta Corporate Governance Perception Index ( CGPI ) Tahun 2012 ). , 3(2011), pp.1-11.

Zabri, Shafie Mohamed \& Ahmad, Kamila . 2015.Corporate Governance Practices and Firm Performance: Evidence from Top 100 Public Listed Companies in Malaysia. Procedia Economics and Finance 35 287 - 296. 